University of Nebraska - Lincoln

DigitalCommons@University of Nebraska - Lincoln

Publications, Agencies and Staff of the U.S.

Department of Commerce

U.S. Department of Commerce

1993

\title{
Seasonal and Annual Variation in Weight and Biochemical Content of the Zebra Mussel, Dreissena polymorpha, in Lake St. Clair
}

\author{
Thomas F. Nalepa \\ NOAA, thomas.nalepa@noaa.gov \\ Joann F. Cavaletto \\ NOAA \\ Mark Ford \\ NOAA \\ Wendy M. Gordon \\ NOAA \\ Marijo Wimmer \\ NOAA
}

Follow this and additional works at: https://digitalcommons.unl.edu/usdeptcommercepub

Part of the Environmental Sciences Commons

Nalepa, Thomas F.; Cavaletto, Joann F.; Ford, Mark; Gordon, Wendy M.; and Wimmer, Marijo, "Seasonal and Annual Variation in Weight and Biochemical Content of the Zebra Mussel, Dreissena polymorpha, in Lake St. Clair" (1993). Publications, Agencies and Staff of the U.S. Department of Commerce. 390.

https://digitalcommons.unl.edu/usdeptcommercepub/390

This Article is brought to you for free and open access by the U.S. Department of Commerce at DigitalCommons@University of Nebraska - Lincoln. It has been accepted for inclusion in Publications, Agencies and Staff of the U.S. Department of Commerce by an authorized administrator of DigitalCommons@University of Nebraska - Lincoln. 


\title{
Seasonal and Annual Variation in Weight and Biochemical Content of the Zebra Mussel, Dreissena polymorpha, in Lake St. Clair
}

\author{
Thomas F. Nalepa, Joann F. Cavaletto, \\ Mark Ford, Wendy M. Gordon, and Marijo Wimmer \\ Great Lakes Environmental Research Laboratory, NOAA \\ 2205 Commonwealth Boulevard \\ Ann Arbor, Michigan 48105
}

\begin{abstract}
Zebra mussels, Dreissena polymorpha, were collected monthly from April/May to November in 1990 and 1991 from two sites in Lake St. Clair. The sites were characterized by relatively high and low mussel densities. The following variables were measured: ash-free dry weight (AFDW) per unit shell length (SL), lipid content and classes, carbon content, and nitrogen content. Mussels from the high-density site had a lower AFDW:SL relationship, lower lipid content, and a lower C:N ratio than mussels from the low-density site. Seasonal trends in these variables were consistent between sites and years. AFDW:SL, lipid, and carbon content were highest in the spring and then declined to minimum levels in late summer/fall. The mean seasonal decline in weight from spring to late summer for a standard 15-mm mussel was $60 \%$. This decline was greater than might be expected from gamete release alone and was likely a result of nutritional stress from warm summer temperatures and limited food supplies. Between 1990 and 1991, the mean AFDW of a 15-mm mussel declined $34 \%$ and 50\% at the high-and low-density site, respectively. However, when C:N ratios and lipid levels in 1990 and 1991 were compared, C:N ratios were only lower in fall 1991 compared to fall 1990, and lipid levels for the 2 years were generally similar.
\end{abstract}

INDEX WORDS: Lipids, carbon, nitrogen, Lake St. Clair, zebra mussels.

\section{INTRODUCTION}

The rapid spread and population increase of the zebra mussel, Dreissena polymorpha, in many regions of North America has led to a need for basic information on interactions between this species and its immediate environment. Of particular importance is the response of Dreissena populations to changes in available food. Filtering activity of mussels has led to a decline in phytoplankton populations in some areas of the Great Lakes (Leach 1993); in turn, declines in food resources may limit future growth of Dreissena. To determine the potential response of Dreissena to changes in food levels, differences in weight and biochemical content of the soft tissue of individual mussels from Lake St. Clair were examined. For mollusks in general, these measures provide an indication of the relative condition or "nutritional state" of the population and provide a basis for assessing response to environmental conditions (Russel-Hunter 1985).

Nutritional state can vary both seasonally and annually. Freshwater and marine bivalves display marked seasonal variations in weight and biochemical content of the soft tissue (Giese et al. 1967, Trevallion 1971, Ansell 1972, Gabbott and Bayne 1973, Beukema and de Bruin 1977, Dietz and Stern 1977, Zandee et al. 1980, Williams and McMahon 1989) that are related to the considerable energetic demands of gametogenesis. Bivalves build up stores of energy in body tissues and then deplete these stores during the production and eventual release of gametes. If reproduction occurs during the summer months, the combination of temperaturerelated metabolic demands and limited food resources can lead to further nutritional stress. For Dreissena, several studies have documented seasonal changes in either weight (Bij de Vaate 1991, Smit and Dudok van Heel 1992) or bioenergetic re- 
serves (Walz 1979, Stanczykowska and Lawacz 1976) of the soft tissue. In addition to short-term, seasonal fluctuations, changes in soft tissue weight can occur over longer periods in response to trends in mussel density and food availability (Stanczykowska et al. 1975).

This paper documents changes in the nutritional state of Dreissena polymorpha populations in southern Lake St. Clair and examines potential causative factors for these changes. Populations in this area of the lake were among the first to become established in North America (Griffiths et al. 1991), and densities increased 10-fold between 1988 and 1989 (Hebert et al. 1991). Although changes in phytoplankton populations have not been previously documented, a decrease in turbidity of water exiting Lake St. Clair via the Detroit River indicates that food resources in the lake are now lower than when the mussel first became established (Hebert et al. 1991). To determine the nutritional state of mussels, the following indicators were measured over a 2 -year period: lipid content and classes, carbon and nitrogen content, and the weight of soft body tissue per unit shell length.

\section{MATERIALS AND METHODS}

Samples of zebra mussels were collected at approximately monthly intervals at two stations (Fig. 1) in southern Lake St. Clair from April to November 1990 and from May to November 1991. The exact locations (longitude and latitude) of the two stations are given in Pugsley et al. (1985). Water depth was $4.0 \mathrm{~m}$ at Station 3 and $5.5 \mathrm{~m}$ at Station 19. These two sites were selected because of differences in bottom types (i.e., proportion of hard substrates), and hence

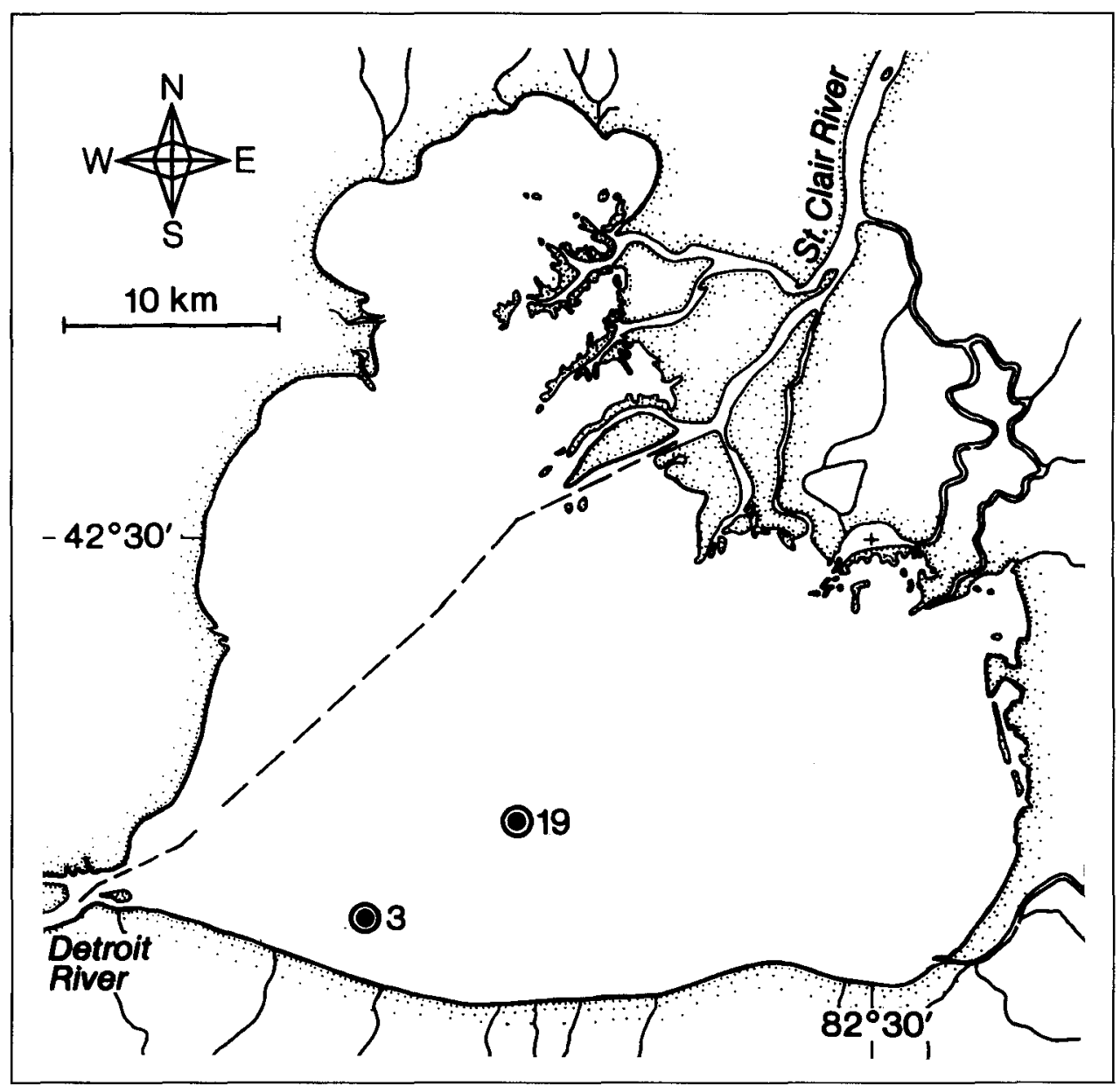

FIG 1. Location of the two sampling sites in southern Lake St. Clair. Dashed line indicates shipping channel. 
differences in densities of zebra mussels. Station 3 had a hard bottom consisting of gravel/pebbles, while Station 19 had a soft bottom consisting of silt/mud. Mussels at Station 3 were found on hard substrata, on live and dead unionid shells, and as druses (clumps of mussels attached to each other). Mussels at Site 19 were found on unionid shells and, in 1991, also as druses. In 1990, densities at Station 3 and 19 were 11,000 and $2,500 \mathrm{~m}^{-2}$, respectively (Nalepa unpublished data). The density at Station 3 was the highest of 29 sampling stations located throughout the lake. On each sampling date, a water sample was taken 1 $\mathrm{m}$ below the surface with a 8 -L van Dorn water bottle for determination of chlorophyll concentrations.

After collection, mussels were gently rinsed in lakewater, placed in coolers containing lakewater, and kept at $4^{\circ} \mathrm{C}$ until analysis. Within $24 \mathrm{~h}$, mussels from each site were separated into five size categories based on relative shell length. The soft tissue of at least five individuals from each size category was removed from the shell, placed individually into combusted, preweighed aluminum planchets, dried at $60^{\circ} \mathrm{C}$ for at least $48 \mathrm{~h}$, and ashed at $550^{\circ} \mathrm{C}$ for $1 \mathrm{~h}$. The corresponding shell was dried, weighed (dry weight only), and the length measured using a digitizer pad. For lipid analysis, soft tissue from each of 5-8 individuals from four of the largest size categories was placed into glass scintillation vials, and then dried at $50^{\circ} \mathrm{C}$ for $48 \mathrm{~h}$. The tissue was then thoroughly pulverized with a mortar and pestle, returned to the same vial, and stored below $0^{\circ} \mathrm{C}$ under nitrogen until analysis. The soft tissue of individuals (5-8) from the smallest size category was not pulverized, but placed whole into small vials and stored as for the larger individuals.

Total lipids were determined on subsamples of soft tissue from individuals in the four largest size categories and on whole individuals for those in the smallest size category. Lipids were extracted and quantified gravimetrically by a micro method (Gardner et al. 1985). Subsamples of the soft tissue were saved and stored below $0^{\circ} \mathrm{C}$ under nitrogen for later determination of lipid classes by thin-layer chromatography with flame ionization detection (TLC-FID) (Parrish 1987, Parrish et al. 1988). Lipid extract from three samples in each size category was spotted directly on silica-coated Chromarods-SIII. Lipid classes were separated by sequentially developing the rods in increasingly polar solvent systems. Between solvent developments, rods were scanned using an Iatroscan Mark IV interfaced with a Hewlett-Packard 3392A integrator. A mixed lipid standard was used for TLC-FID calibration and quantification. The standard included one compound from each of the following lipid classes: hydrocarbon, sterol ester, triacylglycerol, free fatty acid, alcohol (aliphatic), sterol (alicyclic alcohol), and phospholipid. Lipid classes were determined on samples collected in 1990 only.

In 1990, soft tissue from 5-8 individuals in each size category was pulverized and subsamples were analyzed in duplicate for carbon and nitrogen content; in 1991, carbon and nitrogen were determined separately on three individuals from each size category. Carbon and nitrogen content was determined with a Perkin Elmer 2400 CHN Analyzer. Chlorophyll was determined in triplicate as described in Strickland and Parsons (1972) using a Turner fluorometer. Differences in lipids, carbon content, nitrogen content, and $\mathrm{C}: \mathrm{N}$ ratios of mussels at the two stations and in the five size categories were tested using ANOVA. Lipid values were transformed using arcsine prior to analysis.

\section{RESULTS}

\section{Chlorophyll and Temperature}

Chlorophyll concentrations and temperatures on each sampling date are given in Table 1. Concentrations were generally highest in the spring and then declined. Spring chlorophyll values were greater at Station 19 than at Station 3 in both 1990 and 1991, with values 2-4 times greater at the former station during the April/May period. After May, consistent differences between the stations were not apparent. Conceivably, since Station 3 was located closer to shore, the spring peak in chlorophyll may have occurred before the first sampling date and, thus, may have been missed. However, spring temperatures at the two stations in May were generally similar, and the possibility of an earlier peak at Station 3 was unlikely. Annual mean chlorophyll at Station 3 was the same in 1990 and 1991, but mean values at Station 19 were lower in 1991 compared to 1990.

Mean chlorophyll concentrations in this area of the lake in 1990/1991 are lower than concentrations found in the 1970s. In 1971, mean values for stations in the southern and middle portions of Lake St. Clair were 4.6 and $2.9 \mu \mathrm{g} \mathrm{L}^{-1}$, respectively (Leach 1972); also, from 1967-82, the lakewide mean concentration between 1967 and 1982 was $4.7 \mu \mathrm{g} \mathrm{L}^{-1}$ (Herdendorf et al. 1986). In 1991, the mean concentration at the two stations was only 1.2 $\mu \mathrm{g} \mathrm{L}^{-1}$. 
TABLE 1. Temperature $(C)$ and mean $( \pm S E)$ chlorophyll concentrations $\left(\mu g L^{-1}\right)$ at each of the two sampling stations in Lake St. Clair on each sampling date in 1990 and 1991.

\begin{tabular}{|c|c|c|c|c|}
\hline \multirow{2}{*}{$\begin{array}{l}\text { Sampling } \\
\text { Date }\end{array}$} & \multicolumn{2}{|c|}{ Station 3} & \multicolumn{2}{|c|}{ Station 19} \\
\hline & Temp. & Chlorophyll & Temp. & Chlorophyll \\
\hline \multicolumn{5}{|l|}{1990} \\
\hline $18 \mathrm{Apr}$ & 6.5 & $2.1 \pm .15$ & 6.5 & $5.1 \pm .39$ \\
\hline 22 May & 14.5 & $0.6 \pm .03$ & 14.5 & $2.3 \pm .23$ \\
\hline 21 Jun & 22.0 & $1.2 \pm .02$ & 21.5 & $1.1 \pm .07$ \\
\hline $25 \mathrm{Jul}$ & 24.0 & $0.3 \pm .02$ & 24.5 & $1.6 \pm .07$ \\
\hline $23 \mathrm{Aug}$ & 22.0 & $0.7 \pm .01$ & 21.5 & $0.7 \pm .05$ \\
\hline 11 Oct & 13.5 & $2.2 \pm .21$ & 13.5 & $2.7 \pm .14$ \\
\hline $15 \mathrm{Nov}$ & 5.0 & & 6.5 & \\
\hline & \multicolumn{2}{|c|}{ mean: 1.2} & \multicolumn{2}{|c|}{ mean: 2.3} \\
\hline \multicolumn{5}{|l|}{1991} \\
\hline 14 May & 18.5 & $1.0 \pm .05$ & 15.0 & $3.9 \pm .20$ \\
\hline 25 Jun & 23.2 & $2.0 \pm .08$ & 21.8 & $1.7 \pm .08$ \\
\hline $30 \mathrm{Jul}$ & 24.5 & $1.5 \pm .24$ & 23.5 & $0.8 \pm .06$ \\
\hline 27 Aug & 24.0 & $1.3 \pm .02$ & 26.0 & $1.7 \pm .24$ \\
\hline $01 \mathrm{Oet}$ & 14.5 & $1.0 \pm .01$ & 15.5 & $0.4 \pm .03$ \\
\hline $22 \mathrm{Oct}$ & 10.0 & $0.1 \pm .02$ & 10.0 & $0.1 \pm .02$ \\
\hline $21 \mathrm{Nov}$ & 8.0 & $0.3 \pm .02$ & 8.0 & $0.5 \pm .02$ \\
\hline & \multicolumn{2}{|c|}{ mean: 1.0} & \multicolumn{2}{|c|}{ mean: 1.3} \\
\hline
\end{tabular}

\section{Length-Weight}

The relation between ash-free dry weight (AFDW) and shell length (SL) can be described by the general allometric equation $\mathrm{W}=\mathrm{aL}$, where $\mathrm{W}$ is the AFDW of the soft tissue in $\mathrm{mg}$, and $\mathrm{L}$ is the length of the shell in $\mathrm{mm}$. The AFDW:SL relationship (natural log transformed) at the two sites for all sampling dates in 1990 and 1991 was:

Station $3: \log W=-3.8018+2.1514 \log \mathrm{L}$

Station $19: \log W=-4.3096+2.5056 \log \mathrm{L}$

The regressions were significantly different at the two stations $(P<0.05$, analysis of covariance, Zar 1974), with mussels from Station 3 having less weight per unit shell length than mussels from Station 19. Seasonal trends were similar at the two stations. From temporal trends in the regression coefficient "b," AFDW:SL was generally consistent until the end of June, but then steadily declined throughout summer to reach lowest values in fall. To more clearly illustrate seasonal trends in AFDW as well as differences between stations and years, the AFDW of a mussel $15 \mathrm{~mm}$ in length was calculated from the AFDW:SL relationship found at each station on each sampling date (Fig. 2). For all sampling dates, the AFDW of a mussel of this size was 1.6 times greater at Station 19 than at Station 3. The difference between the two stations was greatest in the spring when the AFDW was about 2 times greater at Station 19. AFDW:SL was lower in 1991 than 1990 at both stations; for a $15-\mathrm{mm}$ mussel, the AFDW was 1.5 and 2.2 times lower in 1991 than 1990 at Stations 3 and 19 respectively. The mean AFDW:DW ratio of the soft tissue was 0.88 and ranged from 0.83 to 0.91 . No consistent trends between stations or sampling dates were apparent.

\section{Lipid Content and Lipid Classes}

For all sampling dates during the 2-year period, the mean lipid content at the two stations was $10.0 \%$ (range $6.4-17.7 \%$ ). This mean value compares favorably to the $11.4 \%$ lipid content reported for Dreissena from Lake Constance (Walz 1979), but was lower than the $15.7 \%$ and $17.8 \%$ (two depths) found in mussels from the Fuhliger See, Germany (Sprung and Borcherding 1991). Seasonal trends in lipid content were consistent between years and stations (Fig. 3). Lipid levels were high- 


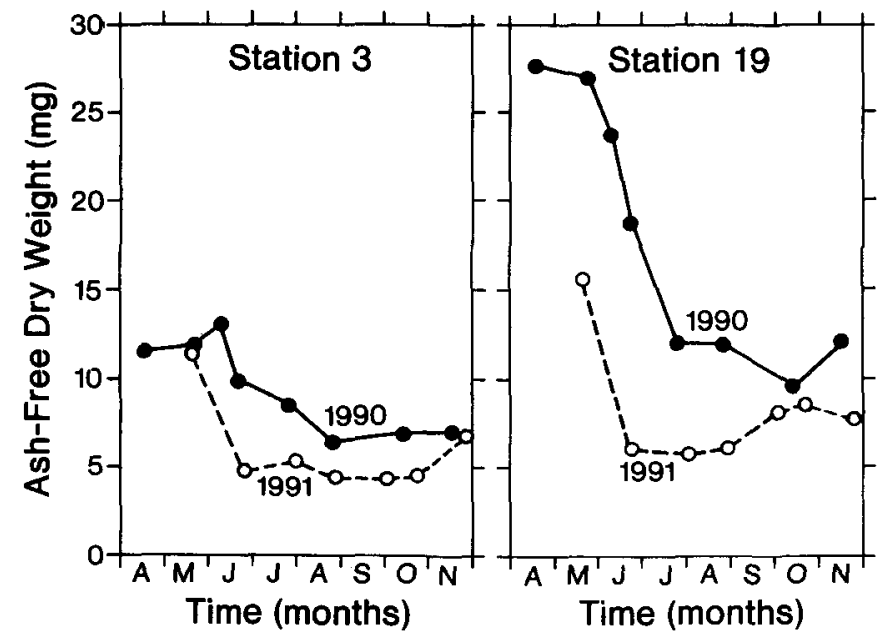

FIG. 2. Seasonal and annual changes in ashfree dry weight of soft tissue of Dreissena polymorpha from the two sampling sites in southern Lake St. Clair in 1990 and 1991. Weights given are for a mussel $15 \mathrm{~mm}$ in shell length and were derived from length-weight regressions determined each sampling date.

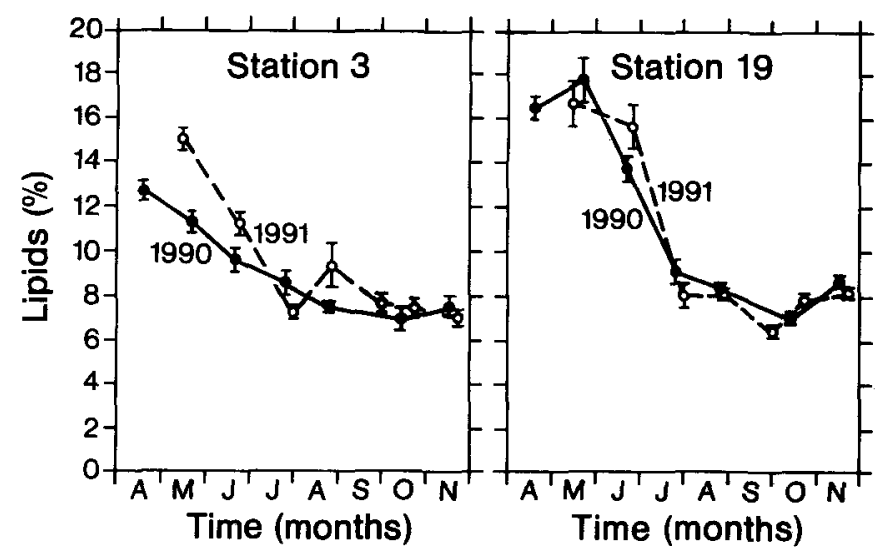

FIG. 3. Mean $( \pm S E$ ) lipid content (percent of dry weight) of Dreissena polymorpha from the two sampling sites in southern Lake St. Clair on sampling dates in 1990 and 1991.

est in spring, and then declined throughout summer; lowest levels occurred in fall. Levels were significantly lower in mussels from Station 3 than in mussels from Station 19 (P<.001; ANOVA; F-value = 12.0). In addition there was a significant interaction between station and size category of mussel $(\mathrm{P}<.05$;
ANOVA; F-value $=4.3$ ). In general, greatest differences between the two stations occurred in the larger-sized mussels; lipid levels declined as mussel size (shell length) increased at Station 3, but this trend did not occur at Station 19 (Table 2). Although lipid levels were higher at Station 3 in spring 1991 compared to spring 1990, consistent differences between years at a particular station were not apparent (Fig. 3).

Mean composition of lipids at the two stations for all dates in 1990 is given in Table 3 . The sum of Iatroscan-measured lipid classes was within $7.1 \pm$ $1.3 \%$ (mean $\pm \mathrm{SE}$ ) of the total value determined with the gravimetric method. At both stations, the dominant lipid class was phospholipids, while the second most important lipid class was triacylglycerols. Phospholipids are essential structural and functional components of all membranes and organelles, while triacylglycerols are chemical stores of energy used during periods of limited food supplies. Triacylglycerol is also used for passing energy to the gametes during gametogenesis. Seasonal trends in triacylglycerols $\left(\mu \mathrm{g} \mathrm{mg}^{-1}\right.$ lipid free dry weight) were similar to trends in total lipids, that is, levels were highest in spring, and then declined throughout summer to reach lowest levels in fall (Fig. 4). Phospholipid levels, on the other hand, remained generally consistent throughout the seasonal sampling period. In comparing the two stations, triacylglycerols were higher in mussels from Station 19, while phospholipids were higher in mussels from Station 3 (Table 3). The ratio between triacylglycerols and phospholipids has been used to assess relative nutritional status in bivalves, with lower values indicating greater nutritional stress (Capuzzo and Leavitt 1988). The ratio (as calculated from the mean percent of total lipid) was 0.5 for mussels from Station 3 and 0.8 for mussels from Station 19. Capuzzo and Leavitt (1988) reported a ratio of 3.5 to 6.6 along a pollution gradient for the marine mussel, Mytilus edulis, but these values were derived from the digestive gland (which serves as a lipid storage organ) and not from whole body tissue as in our study.

\section{Carbon, Nitrogen, and C:N Ratios}

Overall carbon and nitrogen content were significantly different at the two stations $(P<0.05$; ANOVA; F-value $=\mathbf{5 . 6}$ for carbon, 4.5 for nitrogen), with mussels from Station 3 having a lower carbon and higher nitrogen content than mussels from Station 19. Subsequently, the C:N ratio also 
TABLE 2. Mean percent lipid, carbon, and nitrogen of different size zebra mussels from two sampling sites in Lake St. Clair during the 2-year sampling period, 1990-91: Carbon and nitrogen content given as

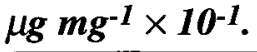

\begin{tabular}{|c|c|c|c|c|c|c|c|c|c|c|}
\hline \multirow[b]{2}{*}{ Size category: } & \multicolumn{5}{|c|}{ Station 3} & \multicolumn{5}{|c|}{ Station 19} \\
\hline & 1 & 2 & 3 & 4 & 5 & 1 & 2 & 3 & 4 & 5 \\
\hline \multicolumn{11}{|l|}{ Year 1990} \\
\hline Length (mm) & 8.1 & 11.9 & 15.1 & 20.0 & 23.2 & 8.2 & 12.0 & 16.3 & 20.6 & 25.6 \\
\hline Lipid (\%) & 11.9 & 8.2 & 9.5 & 8.8 & 8.4 & 11.6 & 9.6 & 11.2 & 11.6 & 12.2 \\
\hline Carbon & 44.0 & 45.5 & 45.6 & 44.3 & 44.3 & 44.3 & 45.1 & 46.9 & 46.2 & 46.7 \\
\hline Nitrogen & 8.9 & 9.2 & 9.5 & 9.2 & 9.7 & 9.2 & 9.3 & 9.0 & 8.8 & 8.2 \\
\hline C:N Ratio & 4.9 & 4.9 & 4.8 & 4.8 & 4.6 & 4.8 & 4.8 & 5.2 & 5.3 & 5.7 \\
\hline \multicolumn{11}{|l|}{ Year 1991} \\
\hline Length (mm) & 10.8 & 12.6 & 16.6 & 19.9 & 23.0 & 11.8 & 15.6 & 19.1 & 22.1 & 25.4 \\
\hline Lipid (\%) & 10.6 & 9.6 & 9.4 & 8.8 & 8.2 & 9.0 & 7.9 & 10.9 & 10.9 & 10.3 \\
\hline Carbon & 46.6 & 47.3 & 45.5 & 45.9 & 44.1 & 48.4 & 48.8 & 46.3 & 47.4 & 45.9 \\
\hline Nitrogen & 10.3 & 10.5 & 10.3 & 10.3 & 10.1 & 9.6 & 10.1 & 9.7 & 10.1 & 9.9 \\
\hline C:N Ratio & 4.5 & 4.5 & 4.4 & 4.5 & 4.4 & 5.0 & 4.8 & 4.8 & 4.7 & 4.6 \\
\hline
\end{tabular}

TABLE 3. Major lipid classes ( $\mu$ g lipid per mg lipid-free dry weight) in Dreissena polymorpha at two sampling stations in Lake St. Clair on all sampling dates in 1990. Values are given as the mean $\pm S E$. Number in parentheses is the percentage of the total lipid concentration. Classes included in the "other" category include hydrocarbons, wax and sterol esters, and methyl esters. TG = triacylglycerols, PL $=$ phospholipids; $A M P L=$ acetone mobile polar lipids, $F F A=$ free fatty acids; $S T=$ sterols.

\begin{tabular}{lccccccc}
\hline & \multicolumn{7}{c}{ Lipid Class } \\
\cline { 2 - 7 } Station & TG & PL & AMPL & FFA & ST & Other \\
\hline 3 & $26.7 \pm 3.9$ & $58.0 \pm 3.3$ & $6.2 \pm 0.5$ & $4.9 \pm 0.7$ & & $6.2 \pm 0.5$ & $2.8 \pm 0.6$ \\
& $(25.3)$ & $(5.6)$ & $(5.9)$ & $(4.7)$ & & $(5.9)$ & $(2.6)$ \\
19 & $37.8 \pm 5.7$ & $48.9 \pm 2.6$ & $10.1 \pm 1.3$ & $6.0 \pm 0.6$ & $7.0 \pm 0.5$ & $3.3 \pm 0.6$ \\
& $(33.4)$ & $(43.2)$ & $(8.9)$ & $(5.3)$ & $(6.2)$ & $(2.9)$ \\
\hline
\end{tabular}
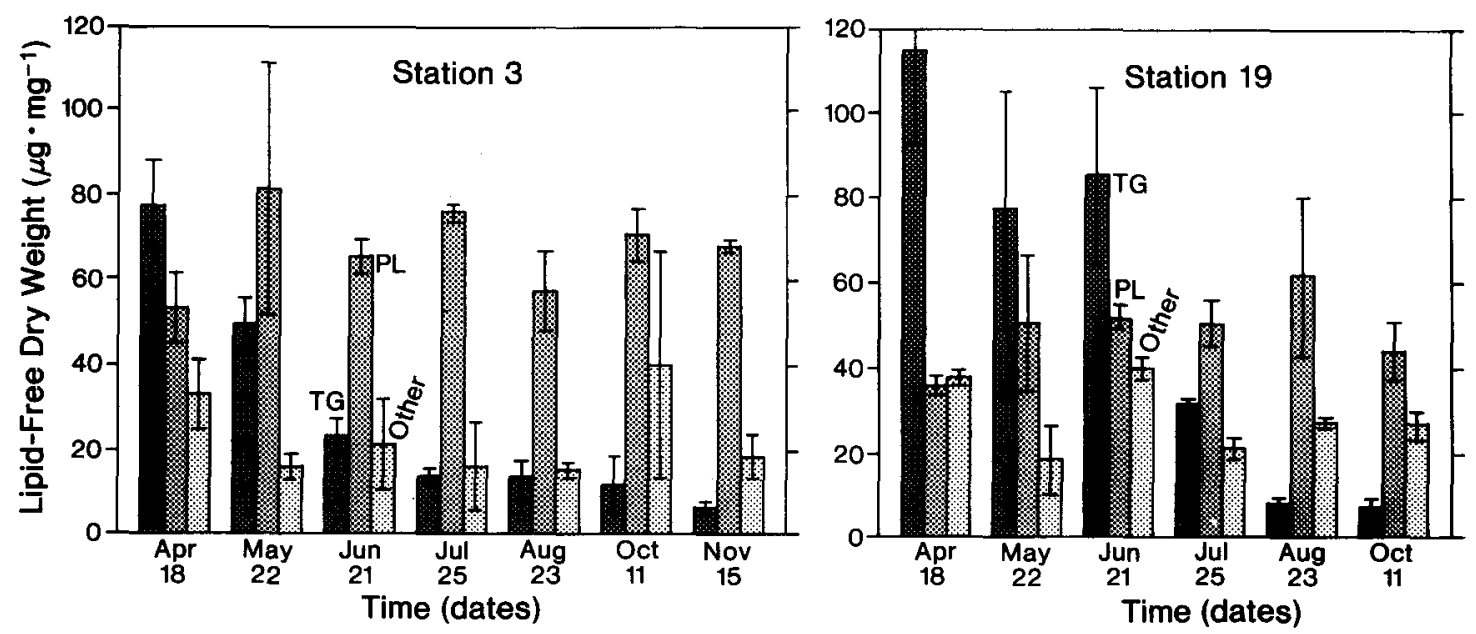

FIG. 4. Seasonal variation (mean $\pm S E$ ) in major lipid classes in Dreissena polymorpha from the two sampling sites in Lake St. Clair in 1990. Values are given as $\mu \mathrm{g}$ lipid per $\mathrm{mg}$ lipid-free dry weight. TG = triacylglycerols; $P L=$ phospholipids; Other = acetone mobile polar lipids, free fatty acids, sterols. 
was also significantly lower for mussels from Station $3(\mathrm{P}<.001$; ANOVA; F-value $=12.8)$. The mean $\mathrm{C}: \mathrm{N}$ ratio for the 2-year sampling period was 4.7 at Station 3 and 5.2 at Station 19. In comparison, Walz (1979) reported a mean annual C: $\mathrm{N}$ ratio of 5.3 for Dreissena from Lake Constance, while Stanczykowska and Lawacz (1976) reported a mean value of 3.6 for Dreissena from Lake Mikolajskie, Poland. Seasonal trends in carbon and nitrogen were generally similar at both stations in 1990 and 1991 (Fig. 5). Carbon content was high in spring and then declined to low levels in fall, while nitrogen was low in spring and increased in fall. As might be expected from these seasonal trends in carbon and nitrogen, $\mathrm{C}: \mathrm{N}$ ratios were greatest in spring and lowest in fall (Fig. 6). At both stations, the ratio was higher in spring 1991 compared to spring 1990, but lower in fall 1991 compared to fall 1990. The apparent decrease in mean $\mathrm{C}: \mathrm{N}$ ratios in 1991 (Table 2) was a result of one less spring sampling date and one more fall sampling date in 1991 compared to 1990 .

\section{DISCUSSION}

Generally, seasonal trends in soft tissue weight for Dreissena in Lake St. Clair are similar to those reported in European populations (Skirkyavichena 1970, Walz 1979, Bij de Vaate 1991, Smit et al. 1992). Maximum weights (AFDW per unit shell length) were observed in spring followed by a general decline to minimum levels in the summer/early fall. These changes have been related to either the reproductive cycle and the release of gametes in late spring/early summer (Bij de Vaate 1991), or to changes in concentrations of available food (Walz 1979). Garton and Haag (1993) reported two distinct periods of weight loss for Dreissena populations in the western basin of Lake Erie: a late spring decline, which was attributed to low abundances of phytoplankton, and a late summer decline, which was attributed to spawning. While certainly the seasonal decline in AFDW:SL in Dreissena from Lake St. Clair was related to the release of gametes, the magnitude of the decline suggests that limited food resources may also be a contributing factor. Dreissena begins to release gametes when water temperatures in the spring rise above $12-14^{\circ} \mathrm{C}$ (Stanczykowska 1977). In Lake St. Clair, these temperatures occurred in late May (Table 1). Mackie (1991) confirmed that the spring reproductive period for Dreissena in southern Lake St. Clair begins between early May and late June. This early

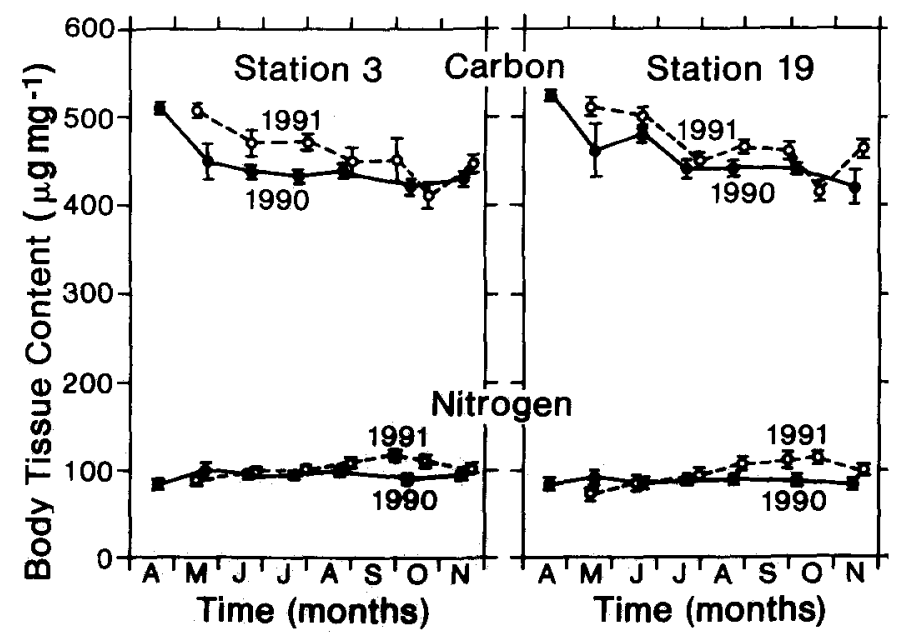

FIG. 5. Mean ( $\pm S E$ ) carbon and nitrogen content $\left(\mathrm{mg} \mathrm{g}^{-1}\right)$ of Dreissena polymorpha from the two sampling sites in southern Lake Clair on sampling dates in 1990 and 1991.

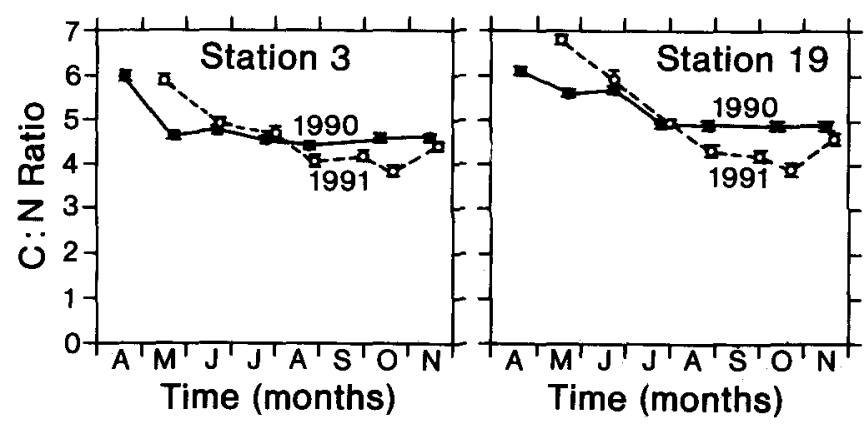

FIG. 6. Mean ( $\pm S E) C: N$ ratio of Dreissena polymorpha from the two sampling sites in southern Lake St. Clair on sampling dates in 1990 and 1991.

May/June time period corresponds to the period of time when large declines in soft tissue weights were found in this study (Fig. 2). The mean decline in AFDW of a 15-mm animal between the spring maximum and the summer/early fall minimum at both stations for the 2 years was $60 \%$ (range $50-65 \%$ ), or about $10 \mathrm{mg}$. The relation between gamete output and body weight in various species of marine bivalves has ranged from 20 to $40 \%$ (see Sprung 1991 for review). For European populations of 
Dreissena, seasonal weight loss has ranged from $10 \%$ to $55 \%$ (Walz 1979, Bij de Vaate 1991), while the mean seasonal weight loss (spring to late summer over 2 years) for Dreissena populations in the western basin of Lake Erie was about $72 \%$ (Garton and Haag 1993). As noted, the seasonal weight decline in the western Lake Erie population occurred over two distinct periods, and the weight decline during each period was about $50 \%$ of the initial weight at the beginning of the period. The portion of weight loss resulting from gamete release in St. Clair mussels can be more clearly defined by using approximations of gamete weight and number of gametes typically produced. Sprung (1991) presented a regression for the direct relationship between gamete output and body size as measured by shell length in Dreissena. Based on this relationship, a female with a shell length of $15 \mathrm{~mm}$ produces about 95,700 eggs. If the AFDW of one egg is about $34 \mathrm{ng}$ (Sprung 1989), weight loss due to gamete release in a $15-\mathrm{mm}$ animal amounts to about $3.3 \mathrm{mg}$, or only about $33 \%$ of the total weight loss observed during the spring to early fall period. Weight loss because of gamete release in males is similar to that for females (Sprung 1991). It is not likely that the decline in AFDW:SL during the summer months was related to differential growth of the shell compared to the soft tissue. Walz (1978d) found that seasonal trends in shell growth and tissue growth were similar in Dreissena from Lake Constance, and Smit et al. (1992) found that shell growth declines during the summer reproductive period in various lakes in the Netherlands.

Although fecundity in bivalves can vary depending on environmental conditions, gamete release apparently only accounted for a portion of seasonal weight loss in mussels from Lake St. Clair. Seasonal trends in food availability may also have contributed to weight declines. In spring and summer, changes in soft tissue weight corresponded to changes in chlorophyll concentrations, which were highest in April/May and declined in late June (Table 1). Soft tissue weights were at minimal values during the summer months when chlorophyll concentrations were at a minimum. While gain or loss of net weight is a function of temperature, food, and mussel size, consistent weight loss occurred under laboratory conditions when algal concentrations were below $100 \mu \mathrm{g}$ carbon/L regardless of size or temperature (range $8-25^{\circ} \mathrm{C}$ ) (Walz 1978c). Assuming a carbon:chlorophyll ratio of 25 (Lingeman-Kosmershock 1978), weight loss should theoretically occur at chlorophyll concentrations below $4 \mu \mathrm{g} / \mathrm{L}$. At the Lake St. Clair sites, chlorophyll concentrations were consistently below this value except at Station 19 in early spring (Table 1). Water temperatures also apparently influenced seasonal weight trends since weight loss did not occur in early spring or fall when temperatures were lower than in summer. Metabolic efficiency (assimilation efficiency, filtering activity) declines when water temperatures rise above $20^{\circ} \mathrm{C}$ (Walz 1978a, Reeders and Bij de Vaate 1990, Schneider 1992). Temperatures in Lake St. Clair were above $20^{\circ} \mathrm{C}$ from June into September (Table 1). Evidence that "metabolic stress" occurred in Lake St. Clair populations of Dreissena during summer is provided by seasonal changes in the relationship between the amount of oxygen respired and the amount of nitrogen excreted (O:N ratio) (Quigley et al. 1993). The $\mathrm{O}: \mathrm{N}$ ratio provides an indication of the relative catabolic balance between carbohydrates, lipids, and proteins and has been used to describe the physiological state of marine mussels (Bayne and Scullard 1977, Widdows 1978, Tedengren and Kautsky 1986). In mussels, individuals with O:N ratios of greater than 50 are considered physiologically "healthy," while individuals with ratios less than 30 are considered "stressed" and catabolyzing internal protein (Bayne et al. 1985). At Station 3 in 1990, ratios declined from about 50 in the spring to a minimum of 16 in the summer (Quigley et al. 1993).

Compared to summer, chlorophyll concentrations in fall increased in 1990 but declined in 1991. Corresponding changes in soft tissue weight in fall were inconsistent, but tended to be higher than summer lows. The phytoplankton community in fall in Lake St. Clair is dominated by chrysophytes, while diatoms dominate in spring (Munawar et al. 1991). The former group is not as nutritionally-rich as the latter and, therefore, less likely to influence the relative condition of mussels. Food quality can be an important factor influencing soft tissue weight (Schneider 1992). However, the general trend for an increase in weight during fall may be more related to reduced metabolic demands because of lower water temperatures and also to the initial stages of gamete regeneration than to food quality.

Although seasonal changes in both lipid content and $\mathrm{C}: \mathrm{N}$ ratios were similar to those for AFSW:SL (i.e., high values in the spring and minimum levels in late summer/fall), it is difficult to determine the relative role of gametogenesis and food availability in influencing seasonal changes in these variables. In general, lipid levels in mollusks are higher in 
gravid than in spent individuals, as energy stores are at a maximum before reproduction and then lower after the gametes are shed (Giese 1966). Lipid levels are also directly related to food concentrations (Walz 1979). C:N ratios provide a direct indication of energy stores; tissue nitrogen content is related to tissue protein content, and a decline in this ratio would indicate a loss of nonproteinaceous energy reserves (lipids and carbohydrates). In freshwater mollusks, $\mathrm{C}: \mathrm{N}$ ratios decrease both during reproduction (Burky 1971, Hunter 1975, Aldridge 1982) and also during periods of low food availability (Russell-Hunter et al. 1984).

The AFDW:SL relationship, lipid content, and $\mathrm{C}: \mathrm{N}$ ratios were significantly lower in mussels at the station with higher densities and lower chlorophyll concentrations (i.e., Station 3). At least for AFDW:SL, spatial differences (both between lakes and within a given lake) have been attributed to variations in local mussel densities and amounts of available food (Stanczykowska 1964, 1979).

Aside from seasonal declines and spatial differences, year-to-year differences in AFDW:SL and biochemical content provide an indication of trends in the relative condition of the population over the long term. In Lake St. Clair, AFDW:SL declined at both sampling stations between 1990 and 1991. To put the decline in AFDW:SL in perspective, the overall AFDW of a standard mussel $15-\mathrm{mm}$ in length was calculated from the length-weight regression found at each station in 1990 and 1991.
The weights were then compared to weights derived from length-weight regressions reported for different Dreissena populations from other regions of the Great Lakes as well as from Europe (Table 4). In 1991, AFDWs of $15-\mathrm{mm}$ mussels from the two sampling sites were lower than any weights calculated from other regressions. The mean loss in weight between 1990 and 1991 was $34 \%$ at Station 3 and $50 \%$ at Station 19. Interestingly, Mackie (1991) gave a length-weight relationship for mussels collected in 1989 (May to November) from a site in Lake St. Clair near Station 3. The decline in weight for a $15-\mathrm{mm}$ mussel was about $54 \%$ between 1989 and 1990, a value that was similar to the loss in weight for mussels at Station 19 between 1990 and 1991 . In western Lake Erie, no yearly differences were apparent in dry weights of mussels in 1989 and 1990 (Garton and Haag 1993).

The decline in AFDW:SL between 1990 and 1991 is consistent with the occurrence of tissue "degrowth" or tissue atrophy in mollusks when food availability does not meet metabolic demands (Russell-Hunter and Eversole 1976, Russell-Hunter 1985). As a result of reabsorbing soft tissue, populations can have high resistance (in terms of mortality) to periods of low food resources. For instance, the freshwater snail $\mathrm{He}$ lisoma trivolis lost $50 \%$ of tissue biomass, but mortality was only $10 \%$ after being starved for 132 days (Russell-Hunter and Eversole 1976). For Dreissena, dry weight declined by $25 \%$, but mortality was only $14 \%$ after being exposed to minimum food levels for

TABLE 4. Comparison of the ash-free dry weights (soft tissue) of an individual Dreissena polymorpha with a shell length of $15 \mathrm{~mm}$ as determined from length-weight relationships. Weights from Lake St. Clair are mean values calculated for each sampling date each year. Ash-free dry weight was assumed to be $87 \%$ of dry weight.

\begin{tabular}{lrll}
\hline Water body, year & $\begin{array}{c}\text { Weight } \\
(\mathrm{mg})\end{array}$ & Reference \\
\hline Lake St. Clair, (Puce), 1989 & 19.6 & & Mackie (1991) \\
Lake St. Clair, (St.19), 1990 & 16.5 & & This study \\
Mazurian Lakes, Poland & 14.5 & & Stanczykowska (1977) \\
Lake IJsselmeer, The Netherlands 1 & 13.5 & & Bij de Vaate (1991) \\
Lake Erie, 1990 & 13.3 & & Dermott et al.(1993) \\
Lake Jels Nederso, Denmark & 9.4 & Kryger and Riisgard (1988) \\
Lake St. Clair (St.3), 1990 & 9.1 & This study \\
Lake St. Clair (St.19), 1991 & 8.3 & This study \\
Lake St. Clair (St.3), 1991 & 6.0 & This study \\
\hline
\end{tabular}

${ }^{1}$ Derived from coefficients for April to November only. 
over 2 years (Walz 1978d). In most cases, tissue degrowth involves proportionately greater losses of nonproteinaceous tissue components (lipids and carbohydrates) than of the protein fraction (RussellHunter 1985). In this study, a 50\% decline in mean weight in mussels at Station 19 between 1990 and 1991 did not result in a decline in the mean annual $\mathrm{C}: \mathrm{N}$ ratio between the two years. However, $\mathrm{C}: \mathrm{N}$ was lower in 1991 during the period of maximum reproductive and nutritional stress (August to October). At Station 19, the minimum C:N ratio declined from 4.9 in 1990 to 3.9 in 1991 during this seasonal period. For the above-mentioned experiment with the freshwater snail Helisoma trivolis, a $50 \%$ weight loss resulted in a decline in the $\mathrm{C}: \mathrm{N}$ ratio from 5.8 to 4.4. Pure protein has a $\mathrm{C}: \mathrm{N}$ ratio of 3.25 (Brody 1964).

Although overall AFDW:SL was lower in 1991 than in 1990 and the $C: N$ ratio in fall 1991 was lower than in fall 1990, lipid levels did not decline between years. Reasons for this inconsistency are not clear, but may indicate carbohydrates are used preferentially to lipids when food levels are below maintenance levels. During starvation experiments with Dreissena, Walz (1979) reported that carbohydrates declined before lipids; however, in similar experiments, Sprung and Borcherding (1991) reported the opposite, that is, lipids decreased prior to carbohydrates. The type of energy reserves used during nutritional stress is likely a function of relative levels; in the former experiments, the carbohydrate content of soft tissue was higher than lipid content, while in the latter experiments lipid levels were higher.

Given the magnitude of the declines in soft tissue weight between 1990 and 1991, the question remains how degrowth of tissue in the individual relates to changes in the population over the long term. In a study of trends in the relative "condition" of Dreissena from Polish lakes, changes over a 10year interval were inversely related to mussel densities; condition declined in lakes where densities increased over a 10-year interval and increased in lakes where densities declined (Stanczykowska et al. 1975). Ultimately, the relationship between tissue degrowth and population densities would be determined by the impacts of degrowth on the reproductive process. In laboratory experiments, starvation caused Dreissena to reabsorb gonadal tissue to meet metabolic needs, but only after spawning occurred (Sprung and Borcherding 1991). Walz (1978b) found that oocytes in Dreissena did not degenerate after a prolonged period of minimal food, but noted that formation of new oocytes would not be likely. Given the amount of tissue degrowth that has been observed in mussels from southern Lake St. Clair and the relatively low food levels (as measured by chlorophyll concentrations), it is likely that population densities, at least in the southern portion of the lake, will stabilize or decline from present levels.

\section{ACKNOWLEDGMENTS}

We wish to thank Bill Burns, Terry Miller, and John Lane for their support and cooperation during field operations and Kathy McElroy for her help in processing some of the samples. GLERL Contribution no. 820 .

\section{REFERENCES}

Aldridge, D. W. 1982. Reproductive tactics in relation to life-cycle bioenergetics in three natural populations of the freshwater snail, Leptoxis carinata. Ecology 63: 196-208.

Ansell, A. D. 1972. Distribution, growth and seasonal changes in biochemical composition for the bivalve Donax vittatus (Da Costa) from Kames Bay, Millport. J. Exp. Mar. Biol. Ecol. 10:137-150.

Bayne, B. L., and Scullard, C. 1977. Rates of nitrogen excretion by species of Mytilus (Bivalvia: Mollusca). J. Mar. Biol. Ass. U. K. 57: 355-369.

Brown, D. A., Burns, K., Dixon, D. R., Ivanovici, A., Livingston, D. R., Lowe, D. M., Moore, M. N., Stebbing, A. R. D., and Widdows, J. 1985. The Effects of Stress and Pollution on Marine Animals. New York: Praeger.

Beukema, J. J., and de Bruin W. 1977. Seasonal changes in dry weight and chemical composition of the soft parts of the tellinid bivalve Macoma balthica in the Dutch Wadden Sea. Nether. J. Sea Res. 11: 42-55.

$\mathrm{Bij}$ de Vaate, A. 1991. Occurrence and aspects of population dynamics of the zebra mussel, Dreissena polymorpha (Pallas, 1771), in the Lake IJsselmeer area (the Netherlands). Oecologia (Berlin): 86: 40-50.

Brody, S. 1964. Bioenergetics and Growth. New York: Hafner Publishing Company, Inc.

Burky, A. 1971. Biomass turnover, respiration, and interpopulation variation in the stream lipid, Ferrissia rivularis (Say). Ecol. Monogr. 41: 235-251.

Capuzzo, J. M., and Leavitt, D. F. 1988. Lipid composition of the digestive glands of Mytilus edulis and Carcinus maenas in response to pollutant gradients. Mar. Ecol. Prog. Ser. 46: 139-145.

Dermott, R., Mitchell, J., Murray, I. and Fear, E. 1993. Biomass and production of zebra mussels (Dreissena polymorpha) in shallow waters of northeastern Lake Erie. In Zebra Mussels: Biology, Impacts, and Control, T. F. Nalepa and D. W. Schloesser (eds.). Boca Raton: Lewis Publishers,Inc. / CRC Press, Inc. 
Dietz, T. H., and Stern E. M. 1977. Seasonal changes in the reproductive activity and biochemical composition of the fingernail clam, Sphaerium transversum. Nautilus 91: 136-140.

Gabbott, P. A., and Bayne, B. L. 1973. Biochemical effects of temperature and nutritive stress on Mytilus edulis L. J. Mar. Bio. Ass. U. K. 53: 269-286.

Gardner, W. S., Frez, W. A., Cichocki, E. A., and Parrish, C. C. 1985. Micromethod for lipid analysis in aquatic invertebrates. Limnol. Oceanogr. 30: 10991105.

Garton, D. W., and Haag, W. R. 1993. Seasonal reproductive cycles and settlement patterns of Dreissena polymorpha in western Lake Erie. In Zebra Mussels: Biology, Impacts, and Control. T. F. Nalepa and D. W. Schloesser (eds.). Boca Raton: Lewis Publishers, Inc./CRC Press, Inc.

Giese, A. C. 1966. Lipids in the economy of marine invertebrates. Physio. Rev. 46: 244-298.

, Hart M. A., Smith, A. M., and Cheung, M. A. 1967. Seasonal changes in body component indices and chemical composition on the pismo clam Tivela stultorum. Com. Biochem. Physiol. 22: 549-561.

Griffiths, R. W., Schloesser, D. W., Leach, J. H., and Kovalak, W. P. 1991. Distribution and dispersal of the zebra mussel (Dreissena polymorpha) in the Great Lakes region. Can. J. Fish. Aquat. Sci. 48: 1381-1388.

Hebert, P. D. N., Wilson. C. C., Murdoch, M. H., and Lazar, R. 1991. Demography and ecological impacts of the invading mollusc Dreissena polymorpha. Can. J. Zool. 69:405-409.

Herdendorf, C. E., Raphael, C. N., and Jaworski, E. 1986. The ecology of Lake St. Clair wetlands: a community profile. U. S. Fish Wildl. Serv. Biol. Rep. 85 (7.7).

Hunter, R. D. 1975. Growth, fecundity, and bioenergetics in three populations of Lymnaea palustris in upstate New York. Ecology 56: 50-63.

Kryger, J., and Riisgard, H. U. 1988. Filtration rate capacities in 6 species of European freshwater bivalves. Oecologia 77: 34-38.

Leach, J. H. 1972. Distribution of chlorophyll a and related variables in Ontario waters of Lake St. Clair. In Proc. 15th Conf. Great Lakes Res., pp. 80-86. Int. Assoc. Great Lakes Res.

1993. Impacts fo the zebra mussel (Dreissena polymorpha) on water quality and fish spawning reefs in western Lake Erie. In Zebra Mussels: Biology, Impacts, and Control, T. F. Nalepa and D. W. Schloesser (eds.). Boca Raton: Lewis Publishers, Inc./CRC Press, Inc.

Lingeman-Kosmershock, M. 1978. Phytoplankton cells, their nutrient contents, mineralisation and sinking rates. Delft Hydraulics, Report R-1310-1.

Mackie G. L. 1991. Biology of the zebra mussel, Dreissena polymorpha, in relation to native bivalves and its potential impact in Lake St. Clair. Hydrobiologia 219:251-268.

Munawar, M., Munawar, I. F., and Sprules, W. G. 1991. The plankton ecology of Lake St. Clair. Hydrobiologia 219: 203-227.

Parrish, C. C. 1987. Separation of aquatic lipid classes by chromarod thin-layer chromatography with measurements by Iatroscan flame ionization detection. Can. J. Fish. Aquat. Sci. 44:722-731.

, Zhou, X., and Herche, L. R. 1988. Flame ionization and flame thermionic detection of carbon and nitrogen in aquatic lipid and humic-type classes with an Iatroscan Mark IV. J. Chromatogr. 435: 350-356.

Pugsley, C. W., Hebert, P. D. N., Wood, G. W., Brotea, G., amd Obal, T. W. 1985. Distribution of contaminants in clams and sediments from the Huron-Erie corridor. I-PCBs and octachlorostyene. J. Great Lakes Res. 11: 275-289.

Quigley, M. A., Gardner, W. S., and Gordon, W. M. 1993. Metabolism of the zebra mussel Dreissena polymorpha in Lake St. Clair of the Great Lakes. In Zebra Mussels: Biology, Impacts, and Control, T. F. Nalepa and D. W. Schloesser (eds.). Boca Raton: Lewis Publishers, Inc. /CRC Press, Inc.

Reeders, H. H., and Bij de Vaate, A. 1990. Zebra mussels (Dreissena polymorpha): a new perspective for water quality management. Hydrobiologia 200/201: 437-450.

Russell-Hunter, W. D. 1985. Physiological, ecological and evolutionary aspects of molluscan tissue degrowth. American Malacological Bulletin 3:213221.

and Eversole, A. 1976. Evidence for tissue degrowth in starved freshwater pulmonate snails (Helisoma trivolis) from tissue, carbon, and nitrogen analysis. Comp. Biochem. Physiol. 54A: 447-453.

Browne, R. A., and Aldridge, D. W. 1984.

Overwinter tissue degrowth in natural populations of freshwater pulmonate snails (Helisoma trivolis and Lymnaea palustris). Ecology 65: 223-229.

Schneider, D. W. 1992. A bioenergetics model of zebra mussel, Dreissena polymorpha, growth in the Great Lakes. Can. J. Fish. Aquat. Sci. 49: 1406-1416.

Skirkyavichena, Z. Y. 1970. The regularities of weight of the Dreissena II. The seasonal effect. Trud. Akad. NAUK Litov. SSR. Ser. C. 2: 91-97.

Smit, H., and Dudok van Heel, E. 1992. Methological aspects of a simple allometric biomass determination of Dreissena polymorpha aggregations. In The Zebra Mussel Dreissena polymorpha: Ecology, Biological Monitoring, and First Applications in Water Quality Management. D. Neumann and H. A. Jenner (eds.). New York: Gustav Fischer Verlag.

, bij De Vaate, A., and Fioole, A. 1992. Shell growth of the zebra mussel (Dreissena polymorpha (Pallas)) in relation to selected physico-chemical 
parameters in the Lower Rhine and some associated lakes. Arch. Hydrobiol. 124: 257-280.

Sprung, M. 1989. Field and laboratory observations of Dreissena polymorpha larvae: abundance, growth, mortality and food demands. Arch. Hydrobiol. 115: 537-561.

1991. Costs of reproduction: a study on metabolic requirements of the gonads and fecundity of the bivalve Dreissena polymorpha. Malacologia 33: 6370.

and Borcherding, J. 1991. Physiological and morphometric changes in Dreissena polymorpha (Mollusca;Bivalvia) during a starvation period. Malacologia 33:179-191.

Stanczykowska, A. 1964. On the relationship between abundance, aggregations and "condition" of Dreissena polymorpha (Pall.) in 36 Mazurian Lakes. Ekologia Polska, Seria A 12: 653-690.

. 1977. Ecology of Dreissena polymorpha (Pall.) (Bivalvia) in lakes. Pol. Arch. Hydrobiol. 24: 461-530.

1979. Size and weight of Dreissena polymorpha in the lakes of western Europe. Gidrobiol. Zh. 13: 26-29.

, and Lawacz, W. 1976. Caloric value of the Dreissena polymorpha (Pall.) dry body weight in some Mazurian lakes. Pol. Arch. Hydrobiol. 23: 271275.

, Schenker, H. J., and Fafara, Z. 1975. Comparative characteristics of populations of Dreissena polymorpha (Pall.) in 1962 and 1972 in 13 Mazurian lakes. Bull. de L'Academie Polonaise des sciences. 23:383-390.

Strickland, J. D. H., and Parsons, T. R. 1972. A Practical Handbook of Seawater Anaylsis. Bulletin 167 (2nd Edition). Fisheries Research Board of Canada, Ottawa.

Tedengren, M., and Kautsky, N. 1986. Comparative study of the physiological physiology and its probable effect on size in blue mussels (Mytilus edulis L.) from the North Sea and the northern Baltic proper. Ophelia 25: 147-155.
Trevallion, A. 1971. Studies on Tellina tenuis Da Costa. III. Aspects of general biology and energy flow. $J$. Exp. Mar. Biol. Ecol. 7:95-122.

Walz, N. 1978a. The energy balance of the freshwater mussel Dreissena polymorpha Pallas in laboratory experiments and in Lake Constance. I. Pattern of activity, feeding and assimilation efficiency. Arch. Hydrobiol. Suppl. 55 (1): 83-105.

1978b. The energy balance of the freshwater mussel Dreissena polymorpha Pallas in laboratory experiments and in Lake Constance II. Reproduction. Arch. Hydrobiol. Suppl. 55 (1): 106-119.

1978c. The energy balance of the freshwater mussel Dreissena polymorpha in laboratory experiments and in Lake Constance. III. Growth under standard conditions. Arch. Hydrobiol. Suppl. 55 (2): 121141.

1978d. The energy balance of the freshwater mussel Dreissena polymorpha in laboratory experiments and in Lake Constance. IV. Growth in Lake Constance. Arch. Hydrobiol. Suppl. 55 (2): 83-105. 1979. The energy balance of the freshwater mussel Dreissena polymorpha Pallas in laboratory experiments and in Lake Constance V. Seasonal and nutritional changes in the biochemical composition. Arch. Hydrobiol. Suppl. 55 (3/4): 235-254.

Widdows, J. 1978. Physiological indices of stress in Mytilus edulis. J. Mar. Biol. Ass. U. K. 58: 125-142.

Williams, C. J., and McMahon, R. F. 1989. Annual variation of tissue biomass and carbon and nitrogen content in the freshwater bivalve Corbicula fluminea relative to downstream dispersal. Can. J. Zool. 67:82-90.

Zandee, D. I., Klutymans, J. H., Zurburg, W., and Pieters, H. 1980. Seasonal variation in biochemical composition of Mytilus edulis with reference to energy metabolism and gametogenesis. Nether. J. Sea Res. 14: 1-29.

Zar, J. H. 1974. Biostatistical Analysis. 2nd Edition. Englewood Cliffs: Prentice Hall, Inc.

Submitted: 7 December 1992

Accepted: 4 June 1993 